\title{
PENERAPAN PENDIDIKAN SEKSUALITAS MELALUI MEDIA LAGU PADA ANAK USIA 5-6 TAHUN GUNA MENINGKATKAN PENGETAHUAN SEKSUALITAS
}

\author{
Riska Ayu Kurniawati ${ }^{1}$, Siti Wahyuningsih ${ }^{1}$, Adriani Rahma Pudyaningtyas ${ }^{1}$ \\ ${ }^{1}$ Pendidikan Guru Pendidikan Anak Usia Dini, Universitas Sebelas Maret \\ E-mail: riskayu@student.uns.ac.id, siti_w@staff.uns.ac.id, adriani.rahmapudyaningtyas@ staff.uns.ac.id
}

\begin{abstract}
Abstrak
Tujuan penelitian ini guna meningkatkan pengetahuan seksualitas melalui media lagu. Pendekatan kuantitatif dan kualitatif yang digunakan dalam penelitian ini. Jenis penelitian tindakan kelas yang dilakukan selama dua siklus. Subjek penelitian yakni anak usia 5-6 tahun di TK At Tamyiz Surakarta. Teknik pengumpulan data menggunakan unjuk kerja, observasi, wawancara, dan dokumentasi. Uji validitas data kualitatif menggunakan triangulasi sumber dan teknik, sedangkan uji validitas data kuantitatif menggunakan validitas konstruk. Teknik analisis data kuantitatif menggunakan analisis data deskriptif komparatif dan analisis data kualitatif menggunakan analisis model interaktif. Hasil penelitian menggambarkan bahwa terdapat peningkatan pada pengetahuan seksualitas anak yaitu persentase ketuntasan pada indikator membedakan laki-laki dan perempuan sebesar 100\%, indikator membedakan organ intim laki-laki dan perempuan sebesar 77,78\% dan indikator melindungi diri dari kekerasan seksual dan bullying sebesar 88,89\%. Peningkatan tersebut ditandai dengan keberhasilan anak dalam membedakan laki-laki dan perempuan, mampu menyebutkan organ intim laki-laki dan perempuan, dan menyebutkan cara melindungi diri dari kekerasan seksual dan bullying. kesimpulan dari penelitian ini adalah penerapan pendidikan seksualitas melalui media lagu dapat meningkatkan pengetahuan seksualitas pada anak usia 5-6 tahun.
\end{abstract}

Kata kunci: pendidikan seksualitas, lagu, pengetahuan seksualitas, anak usia 5-6 tahun

\begin{abstract}
The purpose of this research is to increase knowledge of sexuality through song media. Quantitative and qualitative approaches used in this study. This type of classroom action research conducted for two cycles. Research subjects are children aged 5-6 years at TK Tamyiz Surakarta. Data collection techniques using performance, observation, interviews, and documentation. The validity test of qualitative data uses triangulation of sources and techniques, whereas the validity test of quantitative data uses construct validity. Quantitative data analysis techniques use comparative descriptive data analysis and qualitative data analysis using interactive model analysis. The results described that there was an increase in the knowledge of child sexuality that is the percentage of completeness in the indicators of distinguishing men and women by $100 \%$, indicators of distinguishing intimate organs of men and women by $77.78 \%$ and indicators of protecting themselves from sexual violence and bullying by $88,89 \%$. The increase was marked by the success of children in distinguishing between men and women, being able to mention male and female intimate organs, and mentioning ways to protect themselves from sexual violence and bullying. The conclusion of this research is the application of sexuality education through song media can increase sexuality knowledge in children aged 5-6 years.
\end{abstract}

Keyword: sexuality education, song, sexuality knowledge, children aged 5-6 years

\section{PENDAHULUAN}

Upaya membantu pertumbuhan serta perkembangan jasmani dan rohani supaya anak siap guna memasuki jenjang pendidikan selanjutnya adalah penjabaran dari pendidikan anak usia dini yang berupa pemberian rangsangan pendidikan pada saat anak lahir hingga menginjak usia enam tahun (Kemendikbud, 2014). Modal dasar dalam 
mempersiapkan pendidikan selanjutnya bagi anak yakni memberikan pendidikan usia dini yang tearah dan bersifat holistik . Salah satu aspek yang wajib diperhatikan dalam penyelenggaraan pendidikan anak usia dini adalah perkembangan psikoseksual anak.

Freud (Papalia,2015) masa phallic yakni anak usia 5-6 tahun mulai memperhatikan hal yang berbeda dari jenis kelamin dan mulai ada ketertarikan pada orang tua yang berbeda jenis kelamin. Anak melewati perkembangan seksualitas perlu disertai pengetahuan seksualitas yang sesuai untuk anak usia dini. Pengetahuan seksualitas merupakan informasi tentang perbedaan lakilaki dan perempuan, nama bagian organ intim laki-laki dan perempuan, aturan menjaga daerah privasi, tubuh lakilaki dan perempuan akan berubah ketika beranjak dewasa, mengetahui asal bayi lahir, dan menyentuh area privasi akan memberikan kenikmatan bagi anak (National Child Traumatic Stress Network, 2009).

Kemendikbud (2014) bahwa pengetahuan seksualitas terdapat dalam kompetensi dasar kemampuan menolong diri sendiri untuk hidup sehat. Anak usia 5-6 tahun dikatakan memiliki pengetahuan seksualitas yang baik apabila mampu mencapai indikator perkembangan diantaranya: 1) membiasakan pola hidup bersih dan sehat 2) dapat menjaga diri dari upaya percobaan kekerasan, diantaranya termasuk kekerasan seksualitas dan perundungan. 3) dapat melindungi dan menjauhi diri dari benda-benda berbahaya 4) membiasakan pola makan serta minum yang sehat, bersih dan bergizi. 5) memakai toilet sesuai dengan aturan tanpa bantuan. WHO (2013) menambahkan indikator pencapaian pengetahuan seksualitas usia 5-6 tahun yaitu (1) bagian tubuh dan fungsinya mampu disebutkan oleh anak, (2) organ intim lakilaki dan perempuan mampu diketahui dan dibedakan oleh anak, dan (3) kebersihan organ intim dapat dijaga oleh anak tanpa bantuan. Selanjutnya, Gall (Astuti, 2017) menjabarkan tentang materi-materi pengetahuan seksualitas yang dibutuhkan oleh anak usia dini, diantaranya yaitu: (1) mengenalkan perbedaan yang ada pada lakilaki dan perempuan, (2) pengenalan organ reproduksi dan fungsinya, (3) cara merawat kesehatan organ intim dan (4) kemampuan melindungi diri dari kekerasan seksual. Anak yang sudah mencapai indikator tersebut, maka pengetahuan seksualitas yang dimiliki baik.

Berdasarkan keterangan di atas, diambil tiga indikator untuk penelitian ini yakni sebagai berikut: 1) membedakan lakilaki dan perempuan; 2) membedakan organ intim lakilaki dan perempuan; 3) mampu melindungi diri dari percobaan kekerasan, termasuk kekerasan seksualitas dan bullying (misal dengan berteriak dan/atau berlari).

Hasil dari pengamatan yang dilaksanakan di kelompok B TK At Tamyiz Surakarta, diperoleh bahwa pengetahuan seksualitas anak masih rendah pada indikator 1) membedakan laki-laki dan perempuan; 2) membedakan organ intim laki-laki dan perempuan; 3) mampu melindungi diri dari percobaan kekerasan, termasuk kekerasan seksualitas dan bullying (misal dengan berteriak dan/atau berlari).

Sebanyak 11 anak belum mencapai indikator tersebut dan sebanyak 7 anak lainnya sudah mampu mencapai indikator tersebut.

Rendahnya pengetahuan seksualitas anak dibuktikkan saat beberapa anak masih kesulitan membedakan laki-laki dan perempuan, kemudian saat ditanya tentang organ intim, belum ada jawaban yang tepat yang muncul dari anak-anak. Rata-rata anak menjawab dengan istilah nama organ intim yang bukan sebenarnya. Anak juga belum mengetahui cara melindungi diri dari kekerasan seksual dan bullying. 
Hal tersebut di atas dipengaruhi oleh beberapa faktor. Baik tidaknya pengetahuan seksualitas anak tergantung pada hal-hal yang mempengaruhi disekitarnya. Barimani, dkk (2018) menerangkan bahwa pengetahuan seksualitas dipengaruhi oleh ada 3 faktor, yakni: 1) Faktor yang terkait dengan orang tua: jenis kelamin, wawasan yang tidak memadai, kepedulian yang tinggi, keraguan, rasa malu, ketidakpastian, kurangnya pendidikan, pengetahuan dari sumber yang tidak efektif, persepsi tentang anak dan perannya sebagai orang tua, dan persepsi tentang pendidikan seksual. 2) Faktor terkait guru: jenis kelamin, usia, pengalaman mengajar, kualifikasi akademik, area tempat tinggal, area kerja, status perkawinan, memiliki anak, praktik keagamaan, partisipasi dalam pelatihan pendidikan, pengetahuan yang tidak memadai, ketidakpastian dalam penyediaan pendidikan, kurangnya kenyamanan, rasa malu, khawatir tentang sikap orang tua dan kurangnya akses ke sumber daya pendidikan. 3) Faktor budaya dan terkait masyarakat: tabu seksualitas, kebijakan, budaya keluarga, penerimaan sosial dan budaya, dan sumber daya pendidikan yang terbatas.Lingkungan masyarakat meliputi lingkungan sekitar anak yang masih tabu dalam membicarakan masalah seksualitas (Skripsiadi, 2005). Lingkungan sekolah meliputi cara guru mengajar mengenai pengetahuan seksualitas pada anak, teman sebaya dan media yang digunakan guru untuk mengajarkan pengetahuan seksualitas.

Berdasarkan permasalahan di atas diperlukan suatu solusi, salah satunya adalah penerapan pendidikan seksualitas melalui media lagu. Nurita (2011) mengungkapkan bahwa lagu anak memiliki dampak positif bagi perkembangan afektif anak yaitu memberikan pengaruh pada perilaku anak. Isi lagu bermakna baik, maka pemaknaan yang muncul pada anak juga demikian baik. Segala hal yang disampaikan dalam lagu akan berpengaruh terhadap pengetahuan anak.

Rumusan masalah pada penelitian ini adalah "bagaimanakah penerapan pendidikan seksualitas anak usia dini melalui media lagu anak dapat meningkatkan pengetahuan seksualitas pada anak usia 5-6 tahun?".

Tujuan dari penelitian ini yaitu untuk menggambarkan penerapan pendidikan seksualitas melalui media lagu anak untuk meningkatkan pengetahuan seksualitas pada anak usia 5-6 tahun.

\section{Pengetahuan Seksualitas}

Seksualitas adalah sosial emosional, budaya, dan fisik (National Sexual Violence Resource Center, 2013). Seksualitas jauh lebih luas hubungannya dengan bagaimana perasaan kita dan mengekspresikan diri kita, bagaimana kita membentuk hubungan dengan orang-orang dalam kehidupan kita dan bagaimana kita berada dalam masyarakat (HSE Sexual Health \& Crisis Pregnancy Programme, 2015). Pengetahuan seksualitas dapat dijabarkan menjadi 3 yaitu: kognitif (informasi), afektif (perasaan, nilainilai, dan sikap), dan perilaku (komunikasi, pengambilan keputusan, dan keterampilan lainnya) (Breuner,2016). Pengetahuan seksualitas berisi informasi alasan perubahan dalam tubuh manusia dan cara menjaganya. Anak-anak tidak akan berpikir tentang seksualitas seperti halnya orang dewasa, tetapi anak-anak belajar dan menginterpretasikan hal yang sesuai dengan seksualitas yang akan membentuk perilaku dan tindak tanduk di masa depan mereka.

Pengetahuan seksualitas merupakan informasi tentang perbedaan laki-laki dan perempuan, nama bagian organ intim lakilaki dan perempuan, aturan menjaga daerah privasi, tubuh laki-laki dan perempuan akan berubah ketika beranjak dewasa, mengetahui asal bayi lahir, dan menyentuh area privasi 
akan memberikan kenikmatan bagi anak (National Child Traumatic Stress Network, 2009). Pengetahuan seksualitas pada anak usia 5-6 tahun yang tertuang dalam Permendikbud Nomor 146 Tahun 2014 tentang Kurikulum 2013 Pendidikan Anak Usia Dini terdapat pada kompetensi dasar 4.4, yaitu mampu melindungi diri dari percobaan kekerasan, termasuk kekerasan seksualitas dan bullying (misal dengan berteriak dan/atau berlari). WHO (2013) menambahkan bahwa pengetahuan seksualitas anak usia 5-6 tahun yaitu 1) bagian-bagian tubuh dan fungsinya mampu disebutkan oleh anak, 2) anak mengetahui dan dapat membedakan organ intim laki-laki dan perempuan, dan 3) anak sudah mampu menjaga kebersihan organ intim dengan tanpa bantuan. Didukung Gall (Astuti, 2017) yang berpendapat bahwa pengetahuan seksualitas yang dibutuhkan oleh anak usia dini, diantaranya yaitu: 1) pengenalan perbedaan laki-laki dan perempuan, 2) pengenalan organ reproduksi dan fungsinya, 3) cara merawat kesehatan organ intim dan 4) kemampuan melindungi diri dari kekerasan seksual.

Penjelasan ahli di atas dapat ditarik ringkasan bahwa pengetahuan seksualitas anak usia 5-6 tahun adalah informasi tentang perbedaan laki-laki dan perempuan, perbedaan bagian organ intim laki-laki dan perempuan dan cara melindungi diri dari kekerasan seksual dan bullying.

\section{Pendidikan Seksualitas}

WHO (2013) menerangkan bahwa pendidikan seksualitas akan mempelajari banyak hal dari aspek sosial emosional, kognitif, fisik bahkan interaktif dari segi seksualitas. Masa kanak-kanak awal merupakan masa dimulainya pendidikan seksualitas dan berkembang melalui masa remaja hingga dewasa. Anak-anak dan remaja secara bertahap dilengkapi dan diberdayakan melalui informasi, keterampilan, dan nilainilai positif untuk memahami, menikmati seksualitas dan memiliki hubungan yang aman serta bertanggung jawab atas kesehatan dan kesejahteraan seksual mereka sendiri dan orang lain. Pendidikan seksualitas tidak merusak anak-anak atau remaja (UNESCO, 2009). Pendidikan seksualitas memiliki cakupan berbagai topik yang diselaraskan dengan usia dan tingkat perkembangan seorang anak. Seorang anak berusia 4-6 tahun misalnya belajar tentang topik-topik seperti persahabatan, emosi dan berbagai bagian tubuh.

Chomaria (2014) menjelaskan bahwa pendidikan seksualitas diawali dengan mengenalkan bagian tubuh. Anak prasekolah dapat diberikan pendidikan seksualitas berupa pendidikan tentang area privasi yang mereka miliki (Kliegman et al, 2011). Cara mencegah kekerasan seksualitas agar tidak terjadi pada anak dapat menggunakan solusi penerapan pendidikan seksualitas (Lin, 2011). Orangtua dibantu mengembangkan anak sehat secara seksualitas dengan pemberian pendidikan seksualitas sejak anak usia dini. Self esteem yang lebih baik juga akan dimiliki anak di masa dewasa.

Tujuan dari pendidikan seksualitas yaitu terbentuk landasan kesehatan seks, paham tentang nilai, sikap, dan pengetahuan tentang seks, kemampuan interpersonal saat menghadapi perkara seksualitas berkembang, bertanggung jawab terkait hubungan seksualitas termasuk sandang, larangan dan dorongan untuk terlibat dalam hubungan seksual lebih dini (SIECUS, 2004). Pendidikan seksualitas memberikan bekal pengetahuan untuk jenjang kehidupan berikutnya. (McKee, 2010) mengemukakan tujuan pendidikan seksualitas bagi anak usia dini berkaitan dengan mengajarkan batasan privasi tubuh dan kepemilikan akan tubuh. Hal ini membantu anak-anak memahami mereka memiliki kendali serta tanggunng jawab atas tubuh mereka. Pendidikan seksualitas membantu anak mengerti 
perbedaan konsumsi umum atau privasi dalam masyarakat.

Berdasarkan pendapat beberapa ahli di atas dapat disimpulkan bahwa pendidikan seksualitas adalah upaya memberikan pemahaman pada anak sesuai usianya, mengenai bagian tubuh, cara memelihara organ intim anak, pemahaman perbedaan jenis kelamin, serta upaya pencegahan kekerasan seksual pada anak.

\section{Media Lagu}

Interaksi awal dengan musik secara positif mempengaruhi kualitas semua bidang kehidupan anak-anak (Esimone, 2014). Lagu jelas memainkan banyak peran dalam kehidupan anak-anak yang kemudian menentukan pandangan mereka dalam kehidupan sosial, psikologis dan spiritual mereka. Lagu populer telah mengeksplorasi efek lirik pada pekerjaan sekolah, intersksi sosial, suasana hati dan pengaruhnya terhadap perilaku. Efek dari lirik pada suatu lagu menjadi perhatian utama.

Strait (Dumont, 2017) mengatakan intervensi musik sering dikatakan dapat mempengaruhi bahasa, fisik motorik, sosial, kognitif, dan kemampuan akademik. Lagu pembelajaran dapat menjadi alat meningkatkan fungsi kognitif anak, mengaktifkan cortex yang terhubung dengan kognitif (Sarkamo dalam Dumont, 2017). Hal ini menunjukkan bahwa lagu dapat membantu menjadi media meningkatkan anak memahami pengetahuan seksualitas, karena memicu otak anak aktif saat mendapat rangsangan tersebut sehingga pengetahuan seksualitas yang terkandung dalam lirik lagu dapat dipahami anak.

Murtono

(Bhawono,

2012) menjabarkan bahwa lagu anak isinya berupa kebiasaan sederhana yang sering dilakukan anak. Syair lagu anak sederhana. Lagu yang penuh suka cita dan cerminan etika luhur (Endraswara, 2009). Lagu menjadi sarana media yang efektif untuk proses pembelajaran anak (Rasyid, 2010). Budi pekerti yang diajarkan dalam lagu anak dapat memberi pengaruh baik pada tumbuh kembang anak (Nurita, 2011). Musik dan anak-anak sesungguhnya tidak dapat dipisahkan.

Pengertian-pengertian di atas, dapat diambil kesimpulan bahwa lagu anak-anak adalah kata-kata yang dinyanyikan dengan irama dan nada tertentu, sederhana dan efektif untuk proses pembelajaran anak.

\section{METODE PENELITIAN}

Penelitian dilakukan di TK At Tamyiz Surakarta. Jenis penelitian yang dilakukan yakni penelitian tindakan kelas dengan pendekatan kuantitatif dan kualitatif. Penelitian ini dilaksanakan dalam dua siklus yang setiap siklus terdiri dari dua kali pertemuan. Setiap siklus terdiri dari perencanaan, pelaksanaan, observasi, dan refleksi. Subjek penelitian adalah anak usia 56 tahun dengan jumlah 18 anak terdiri dari 6 anak laki-laki dan 12 anak perempuan. Sumber data dalam penelitian ini adalah anak dan guru. Teknik pengumpulan data dalam penelitian ini menggunakan tes, observasi, wawancara dan dokumentasi.

Validitas konstruk digunakan pada teknik uji validitas data kuantitatif dan triangulasi sumber dan triangulasi teknik yang digunakan dalam teknik uji validitas data kualitatif. Analisis data komparatif digunakan untuk teknik analisis data kuantitatif, sedangkan analisis data kualitatif model interaktif Miles dan Huberman digunakan untuk teknik analisis data kualitatif. Teknik analisis data model interaktif terdiri dari pengumpulan data, reduksi data, penyajian data, dan penarikan kesimpulan.

\section{HASIL DAN PEMBAHASAN}

Pengetahuan seksualitas anak dari pratindakan, siklus 1, hingga siklus 2 mengalami peningkatan. Hal ini terbukti dari 
hasil penilaian tiap siklusnya dari masingmasing indikator yaitu membedakan lakilaki dan perempuan, membedakan organ intim laki-laki dan perempuan, dan mampu melindungi diri dari kekerasan seksual. Berikut diagram hasil persentase

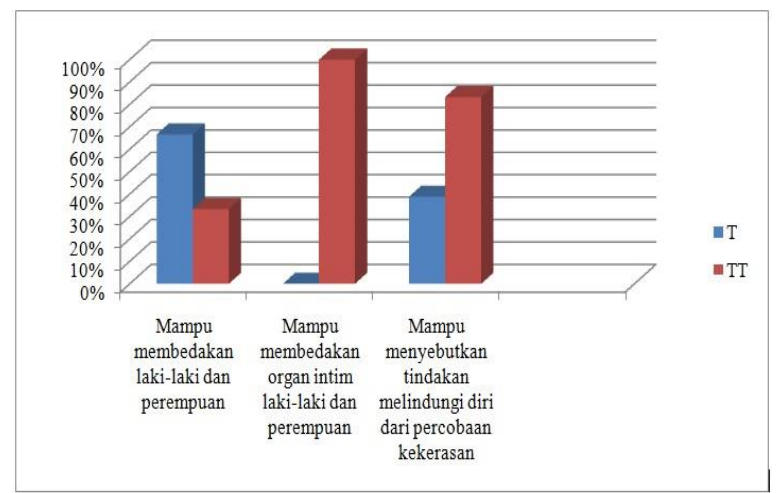

Gambar 1 Diagram hasil persentase pengetahuan seksualitas anak pratindakan pengetahuan seksualitass anak pratindakan:

Berdasarkan hasil pratindakan pengetahuan seksualitas pada anak usia 5-6 tahun dapat disimpulkan bahwa sebesar 33,33\% atau sebanyak 6 anak belum mampu membedakan laki-laki dan perempuan.

Indikator membedakan organ intim laki-laki dan perempuan diperoleh data sebesar $100 \%$ atau sebanyak 18 anak belum mampu membedakan organ intim laki-laki dan perempuan. Ketika observer bertanya tentang nama organ intim laki-laki dan perempuan belum ada anak yang bisa menjawab dengan tepat, anak-anak hanya mengetahui sebutan burung bagi organ intim laki-laki. Indikator melindungi diri dari kekerasan seksual dan bullying diperoleh data sebesar 72,22\% atau sebanyak 13 anak belum mampu mencapai indikator tersebut. Anak-anak saat mendapat bullying cenderung menangis dan mengadu ke guru. Ketika anak ditanya cara melindungi diri apabila mendapat kekerasan seksual anak masih kebingungan, karena anak belum memahami bagian tubuh yang boleh dan tidak boleh disentuh orang lain yang menimbulkan kekerasan seksual.

Setelah dilaksanakan tindakan pada siklus 1, terdapat peningkatan pada pengetahuan seksualitas anak. Hasil ketuntasan siklus 1 pada setiap pertemuan dapat dilihat pada tabel 1 berikut:

Tabel 1 Hasil Ketuntasan Pengetahuan Seksualitas Siklus 1

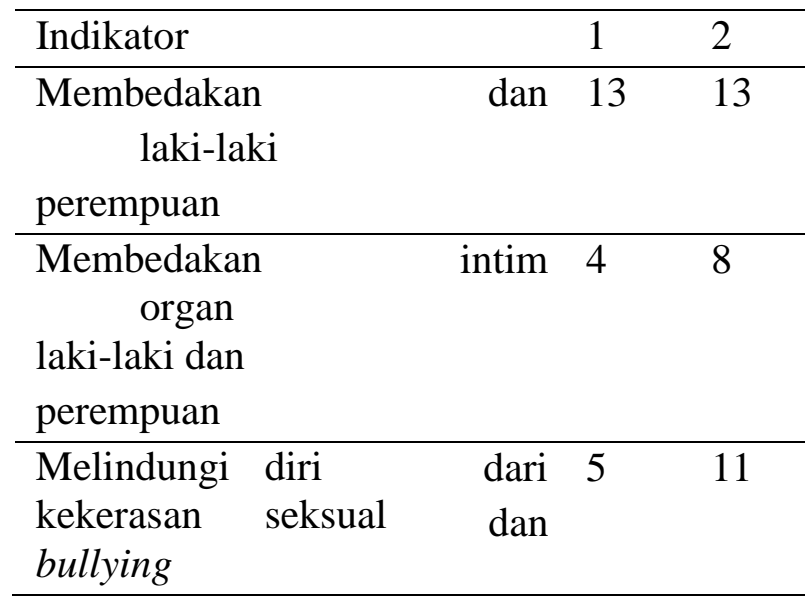

Peningkatan pengetahuan seksualitas siklus 1 pada tiap indikatornya yakni: membedakan laki-laki dan perempuan yang tuntas didapatkan saat anak dapat menunjukkan perbedaan laki-laki dan perempuan mulai dari pakaian yang digunakan, menyebutkan anggota keluarga sesuai jenis kelaminnya. Anak yang tuntas pada indikator membedakan organ intim lakilaki dan perempuan terlihat saat beberapa anak sudah mampu menjawab pertanyaan guru tentang nama organ intim laki-laki dan perempuan. Anak yang tuntas pada indikator melindungi diri dari kekerasan seksual dan bullying terlihat dari anak mampu menunjukkan cara melindungi diri dari kekerasan seksual seperti berlari, bilang ke ayah bundanya.

Pengetahuan seksualitas anak saat pratindakan masih belum tuntas tapi setelah dilakukan tindakan pada siklus 1 terdapat 
peningkatan hasil ketuntasan klasikal pengetahuan seksualitas anak usia 5-6 tahun yang dapat dilihat pada tabel 2 berikut ini:

Tabel 2 Hasil Ketuntasan Klasikal

Pengetahuan Seksualitas Anak Usia 5-6

Tahun

\begin{tabular}{lll}
\hline Kriteria Ketuntasan & F & Persentase \\
\hline Tuntas & 10 & $55,56 \%$ \\
Tidak Tuntas & 8 & $44,44 \%$ \\
\hline Jumlah & 18 & $100 \%$ \\
\hline
\end{tabular}

Berdasarkan tabel 2 tersebut dapat dijabarkan bahwa hasil persentase ketuntasan pengetahuan seksualitas anak secara klasikal pada siklus 1 adalah anak tidak tuntas. Anak yang tuntas yakni ketika memperoleh skor 3 dan 4, sedangkan anak yang belum tuntas mendapat skor 1 dan 2. Hasil persentase ketuntasan pratindakan apabila dibandingkan didapatkan pengetahuan seksualitas anak mengalami peningkatan sebanyak $16,68 \%$. Persentase ketuntasan pengetahuan seksualitas anak secara klasikal pada siklus 1 belum memenuhi target pencapaian yang ditetapkan yakni $75 \%$, maka perlu dilakukan tindakan selanjutnya dengan melihat refleksi siklus 1. Refleksi siklus 1 diantaranya, beberapa anak ada yang belum antusias menyanyikan lagu karena belum hafal liriknya. Beberapa anak belum memenuhi standar kriteria penilaian pada masingmasing indikator. Anak-anak berdesakdesakan saat bernyanyi sambil bergerak.

Berdasarkan refleksi pada siklus 1 maka dapat diberikan solusi berupa: memberikan video pengantar dan pengulangan. mengatur posisi masingmasing anak sebelum bernyanyi, memberikan permainan pada anak-anak agar termotivasi untuk dapat mencapai standar ketuntasan penilaian pengetahuan seksualitas dari masing-masing indikator.
Siklus 2 mengalami peningkatan yang signifikan pada pengetahuan seksualitas anak usia 5-6 tahun. Hasil pengetahuan seksualitas anak pada siklus 2 dapat dillihat pada tabel 3 berikut ini:

Tabel 3 Hasil Ketuntasan Pengetahuan Seksualitas Siklus 2

\begin{tabular}{llll}
\hline Indikator & & 1 & 2 \\
\hline \begin{tabular}{l} 
Membedakan \\
\multicolumn{1}{l}{ laki-laki }
\end{tabular} & dan & 15 & 18 \\
perempuan & & & \\
\hline $\begin{array}{l}\text { Membedakan } \\
\text { organ }\end{array}$ & intim & 12 & 14 \\
$\begin{array}{l}\text { laki-laki dan } \\
\text { perempuan }\end{array}$ & & & \\
\hline $\begin{array}{l}\text { Melindungi diri } \\
\text { kekerasan seksual } \\
\text { bullying }\end{array}$ & dari & 14 & 16 \\
\hline
\end{tabular}

Hasil pengetahuan seksualitas anak yang tuntas pada siklus 2 yakni pada indikator membedakan laki-laki dan perempuan, anak sudah mampu membedakan laki-laki dan perempuan dilihat dari pakaian, rambut, dan mengelompokkan teman-teman kelas sesuai jenis kelaminnya. Hal ini didukung setelah peneliti mengajak anak bernyanyi lagu "berpakaian sunnah" berulang-ulang. Indikator membedakan organ intim laki-laki dan perempuan anak sudah mampu menyebutkan nama organ intim dengan benar. Indikator melindungi diri dari kekerasan seksual dan bullying anak sudah mampu menyebutkan cara melindungi diri dengan berlari, berteriak, bilang ke ayah bunda atau guru. Hal ini termuat dalam lagu "sentuhan boleh" dan "inilah tubuhku". Anak riang menyanyikan lagu tersebut disertai dengan gerakan. Anak mampu menandai anggota tubuh yang boleh dan tidak boleh disentuh pada papan gambar yang disediakan peneliti. 
Peningkatan yang signifikan terjadi disiklus 2 dilihat dari persentase ketuntasan pengetahuan seksualitas secara klasikal. Hasil persentase ketuntasan klasikal pengetahuan seksualitas siklus 2 dapat dilihat pada tabel 4 berikut ini:

Tabel 4 Hasil persentase ketuntasan klasikal pengetahuan seksualitas siklus 2

\begin{tabular}{lll}
\hline Kriteria Ketuntasan & F & Persentase \\
\hline Tuntas & 15 & $83,33 \%$ \\
Tidak Tuntas & 3 & $16,67 \%$ \\
\hline Jumlah & 18 & $100 \%$ \\
\hline
\end{tabular}

Tabel 4 di atas menjabarkan bahwa persentase ketuntasan secara klasikal pengetahuan seksualitas anak pada siklus 2 yaitu 83,33\% atau 15 anak tuntas dan 16,67\% atau 3 anak tidak tuntas. Apabila dibandingkan dengan hasil persentase ketuntasan pratindakan maka pengetahuan seksualitas anak mengalami peningkatan sebanyak 44,45\%. Capaian persentase ketuntasan klasikal siklus 2 yakni 83,33\%, sehingga tuntas mencapai target yang ditetapkan sebesar $75 \%$.

Refleksi pada siklus 2 adalah memberikan aturan permainan pada anakanak agar termotivasi untuk dapat mencapai standar ketuntasan penilaian pengetahuan seksualitas dari masing-masing indikator. Hasil unjuk kerja pengetahuan seksualitas pada siklus 2 telah mencapai target yaitu sebesar $75 \%$.

Pengetahuan seksualitas pada anak usia 5-6 tahun mengalami peningkatan yang signifikan, perbandingan hasil pengetahuan seksualitas anak antar siklus dapat dilihat pada tabel 5 di bawah ini:

Tabel 5 Perbandingan Hasil Pengetahuan
Seksualitas Anak Antar Siklus

\begin{tabular}{|l|c|c|c|c|}
\multirow{2}{*}{ Pratindakan } & \multicolumn{2}{|c|}{ Siklus 1 } & \multicolumn{2}{c|}{ Siklus 2 } \\
\cline { 2 - 5 } & 1 & 2 & 1 & 2 \\
\hline $38,88^{\circ} \circ$ & $44,44_{0}^{\circ}$ & $55,56^{\circ} \%$ & $77.78^{\circ} \%$ & $83,33^{\circ}$ \\
$(7$ anak $)$ & $(8$ anak $)$ & (10 anak) & (14 anak) & $(15$ anak $)$ \\
\hline
\end{tabular}

Tabel tersebut menunjukkan peningkatan pada pengetahuan seksualitas anak secara klasikal dengan penerapan pendidikan seksualitas melalui media lagu. Perkembangan pengetahuan seksualitas anak mulai dari pratindakan, siklus 1 hingga siklus 2 mengalami peningkatan. Hal tersebut dapat disajikan dalam bentuk gambar diagram di bawah ini:

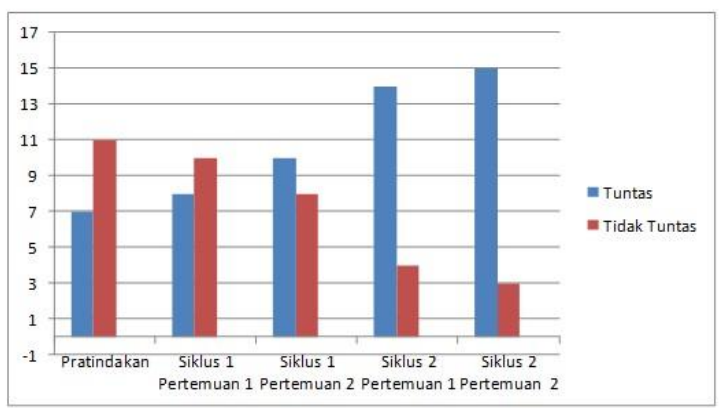

Gambar 2 Perbandingan Hasil Pengetahuan Seksualitas Anak Antar Siklus

Diagram tersebut menggambarkan bahwa perolehan ketuntasan pengetahuan seksualitas secara klasikal dari pratindakan, siklus 1, siklus 2 dapat dijabarkan bahwa pengetahuan seksualitas pada pratindakan, persentase ketuntasan anak sebesar 38,88\% atau 7 anak yang tuntas. Pengetahuan seksualitas anak pada siklus 1 mengalami peningkatan sebanyak $16,68 \%$ menjadi $55,56 \%$ atau sebanyak 10 anak tuntas. Peningkatan berlanjut pada siklus 2 yakni sebesar 44,45\% menjadi 83,33\% atau 15 anak tuntas. Hasil penelitian yang telah dilakukan dapat disimpulkan berhasil sebab dengan penerapan pendidikan seksualitas menggunakan media lagu, pengetahuan 
seksualitas pada anak dapat meningkat. Peningkatan tersebut terlihat pada setiap siklus dalam pengetahuan seksualitas anak.

Anak yang belum mencapai ketuntasan sampai akhir penelitian sebanyak tiga anak. Ketiga anak tersebut belum mencapai kategori tuntas pada tiap indikator.

Anak belum mencapai nilai tuntas disebabkan oleh beberapa faktor yaitu pertama didapati bahwa menurut guru salah satu anak tersebut memiliki kebutuhan khusus karena di kegiatan yang lain anak juga terlambat dalam mengikuti pembelajaran. Kedua, anak tidak menghiraukan pembelajaran karena faktor usianya yang lebih muda dari teman-teman yang lain namun masuk dalam kelompok B mengikuti sang kakak.

Berdasarkan hasil pengamatan peneliti, beberapa anak menyebutkan organ intim dengan sebutan lain. Hal ini karena orang tua yang enggan menjelaskan dengan nama sebenarnya dan memilih dengan julukan lain yang membuat anak bingung. Sesuai dengan pendapat Barimani, dkk (2018) menerangkan salah satu faktor yang mempengaruhi pengetahuan seksualitas faktor yang terkait dengan orang tua: jenis kelamin, wawasan yang tidak memadai, kepedulian yang tinggi, keraguan, rasa malu, ketidakpastian, kurangnya pendidikan, pengetahuan dari sumber yang tidak efektif, persepsi tentang anak dan perannya sebagai orang tua, dan persepsi tentang pendidikan seksual. Selain itu, anak juga terpengaruh oleh teman sebaya yang memiliki latar belakang keluarga yang kasar dalam kesehariannya. Anak terbawa perilaku dan perkataan teman sebaya tersebut. Hal ini selaras dengan pendapat (Skripsiadi, 2005) bahwa lingkungan masyarakat dan lingkungan sekilah menjadi faktor eksternal yang mempengaruhi pengetahuan seksualitas anak. Selanjutnya, ketiga anak yang belum tuntas tersebut kemudian diberi pendampingaan, motivasi agar anak dapat tuntas, dan memberikan waktu tambahan mengajak anak bernyanyi sambil bermain yang diselipi kuis. Selain itu, Guru juga membagikan lagu yang diajarkan peneliti pada orangtua anak agar orangtua dapat mengulas kembali pembelajaran sebagai upaya penerapan pendidikan seksualitas pada anak di rumah.

Penerapan pendidikan seksualitas oleh orangtua di rumah diharapkan dapat meningkatkan kesadaran orangtua tentang pentingnya pengetahuan seksualitas bagi anak. Hal ini akan membuat anak akan lebih tegas dan percaya diri dalam bertindak melindungi diri apabila ada oranglain yang memegang area pribadi tanpa izin. Anak juga mendapatkan pemahaman yang benar tentang organ intimnya. Merujuk pendapat Nugraha (Pramitasari, 2017) pendidikan seksualitas untuk anak usia dini ialah usaha memberi pengertian sesuai usia, tentang fungsi organ intim, bimbingan menjaga kesehatan organ intim, memberi arahan tentang perilaku pergaulan sehat serta risikorisiko seputar masalah seksualitas.

Penerapan pendidikan seksualitas melalui media lagu anak membantu membangun daya ingat anak tentang pengetahuan seksualitas dan memupuk keberanian dalam mengekspresikan perasaan dalam hal ini yang berkaitan dengan rasa tidak nyaman apabila mengalami kekerasan seksual. Hal tersebut sejalan dengan pendapat Masitoh (2009) yang menjelaskan bahwa bernyanyi lagu anak-anak ada empat manfaat yakni menenangkan, atasi cemas, untuk mengekspresikan perasaan, membantu perkembangan daya ingat anak.

\section{PENUTUP}

\section{Simpulan}

Hasil dari penelitian ini diperoleh data bahwa penerapan pendidikan seksualitas melalui media lagu dapat meningkatkan pengetahuan seksualitas pada anak usia 5-6 
tahun berupa indikator membedakan lakilaki dan perempuan, membedakan organ intim laki-laki dan perempuan serta melindungi diri dari kekerasan seksual dan bulliying.

\section{Saran}

Guru dapat menggunakan lagu lain untuk menyisipkan pengetahuan seksualitas

\section{DAFTAR PUSTAKA}

Astuti, B., Sugiyatno, S., \& Aminah, S. (2017). The development of early childhood sex education materials for childhood education teachers.

Jurnal Pendidikan dan

Pemberdayaan Masyarakat, 4 (2),

113-120. Retrieved from http:/journal.uny.ac.id/index.php/jpp $\mathrm{m}$.

Barimani, dkk. (2018). Factors influencing children's sexual health. Iran: Mazandaran University.

Bhawono, P. (2012). Metode pengembangan lagu anak pada anak usia dini di SPS POS PAUD Sekecamatan Godean. Yogyakarta: Universitas Negeri Yogyakarta.

Chomaria, N. (2014). Pelecehan anak, kenali dan tangani, menjaga buah hati dari sindrom. Solo: Tiga

Serangkai.

Dumont, dkk. (2017). Music interventions and child development: a critical review and further. Frontiers in Psychology, 8(1694), 120. Doi:

10.3389/fpsyg.2017.01694.

Endraswara, S. (2003).

Metodologi penelitian folklor.

Yogyakarta: Medpress.

Esimone. (2014). Music in early childhood education: its importance in selected child development. Journal of Educational and Social Research, didalam lagu. Penerapan pendidikan seksualitas diharapkan dapat dilaksanakan secara konsisten. Saran untuk peneliti selanjutnya dapat memberikan variasi penggunaan media lagu untuk meningkatkan pengetahuan seksualitas anak.

4(1), 39-43. Doi:

10.590/jesr.2014.v4n1p39.

HSE Sexual Health \& Crisis Pregnancy Programme. (2015). The talking to your child about relationship, sexuality and growing up. Retrieved from www.sexualwellbeing.ie.

Kemendikbud. (2014). Peraturan menteri pendidikan dan kebudayaan nomor 146 tahun 2014 tentang kurikulum 2013 pendidikan anak usia dini. Jakarta: Kemendikbud.

Lin, D. (2011). Child sexual abuse and its relationship with health risk behaviors among rural children and adolescents in hunan, China.

Masitoh. (2009). Strategi pembelajaran TK. Jakarta: Universitas Terbuka.

National Sexual Violence Resource Center. (2013). An overview of healthy childhood sexual development. Retrieved from http://www.nsvrc.org.

Kliegman, R. (2011). Nelson textbook of pediatrics. Philadelphia: Elsevier.

Papalia, E. D. (2015). Human development (psikologi perkembangan) edisi kesembilan. Jakarta: PRENADANEDIA GROUP.

Pramitasari\&Ningrum. (2018). Pengembangan permainan engklek dalam memberikan pendidikan seks bagi anak usia dini. Surabaya: Universitas Negeri Surabaya.

Rasyid, F. (2010). Cerdaskan anakmu dengan musik. Yogyakarta: Diva 
Press.

Skripsiadi, E. J. (2005). Pendidikan dasar seks untuk anak. Yogyakarta: Curiosita.

The National Child Traumatic Stress Network. (2009). Sexual development and behavior in children-information for parents\&caregivers. US: Substance Abuse and Mental Health Services Administration.

The Sexuality Information and Education Council of the United States (SIECUS). (2006). Families are talking. Retrieved from http://www.familiesaretalking.org.

UNESCO. (2009). International. Technical guidance on sexuality education-an evidence-informed approach for schools, teachers and health educators. Paris

WHO Regional Office For Europe and Bzga. (2013). The guidance for implementation was jointly developed by the federal center for health education. Bzga: WHO. 